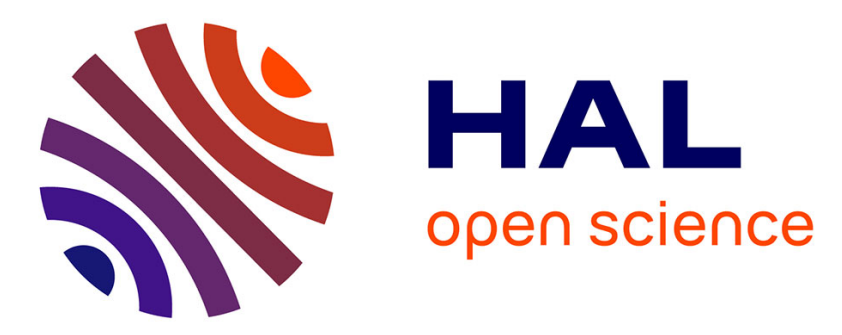

\title{
Interaction between deformation and sedimentation in a multidecollement thrust zone: Analogue modelling and application to the Sub-Andean thrust belt of Bolivia
}

Lena Driehaus, Thierry Nalpas, Jean-François Ballard

\section{- To cite this version:}

Lena Driehaus, Thierry Nalpas, Jean-François Ballard. Interaction between deformation and sedimentation in a multidecollement thrust zone: Analogue modelling and application to the Sub-Andean thrust belt of Bolivia. Journal of Structural Geology, 2014, 65, pp.59-68. 10.1016/j.jsg.2014.04.003 . insu-00993481

\section{HAL Id: insu-00993481 \\ https://hal-insu.archives-ouvertes.fr/insu-00993481}

Submitted on 20 May 2014

HAL is a multi-disciplinary open access archive for the deposit and dissemination of scientific research documents, whether they are published or not. The documents may come from teaching and research institutions in France or abroad, or from public or private research centers.
L'archive ouverte pluridisciplinaire $\mathbf{H A L}$, est destinée au dépôt et à la diffusion de documents scientifiques de niveau recherche, publiés ou non, émanant des établissements d'enseignement et de recherche français ou étrangers, des laboratoires publics ou privés. 


\title{
Interaction between deformation and sedimentation in a multidecollement thrust zone:
} analogue modelling and application to the Sub-Andean thrust belt of Bolivia

\author{
Lena DRIEHAUS $^{\mathrm{a}, \mathrm{b}}$, Thierry NALPAS ${ }^{\mathrm{a}, *}$, Jean-François BALLARD ${ }^{\mathrm{c}}$
}

a Géosciences Rennes, Université de Rennes 1, UMR 6118 du CNRS, Campus de Beaulieu, 35042 Rennes cedex, France

b Departament de Geodinàmica i Geofísica, Facultat de Geologia, Universitat de Barcelona (UB) C/ Martí i Franquès s/n, 08028-Barcelona, Spain.

c Total EP, CSTJF, Avenue Larribau, 64018 Pau Cédex, France

* Corresponding author. Tel.: +33 223235675; fax: +33 223236100.

E-mail address: thierry.nalpas@univ-rennes1.fr (T. Nalpas).

Keywords: Compressive system; Decollement; Synkinematic sedimentation; Experiment; Incahuasi

\section{ABSTRACT}

Fold and thrust belts are influenced by the presence of decollement levels, as well as the amount of shortening and synkinematic sedimentation. These parameters are studied at the scale of a thrust belt using a field approach, combined with analogue and numerical modelling. In this study, we use analogue modelling to test the evolution of a single structure during sedimentation in a domain containing three prekinematic decollement levels. The development of this structure in the analogue experiments shows that the expression of the deformation is strongly dependent on sedimentation rate: (i) the structure propagates forward in an overall asymmetric shape if the sedimentation rate is slower than the uplift velocity, or (ii) the structure grows vertically and its vergence changes at the surface if the sedimentation rate is similar to the uplift velocity, or (iii) the structure grows 
vertically with a double vergence at the surface and at depth if the sedimentation rate is higher than the uplift velocity. The results of the experiments are compared with structures in the Subandean thrust belt to aid the interpretation of poor seismic data.

\section{Introduction}

The deformation observed in compressive systems such as fold and thrust belts is influenced by the presence of decollement levels (e.g. Dunn et al., 1995; Labaume and Moretti, 2001; Sepehr et al., 2006; Verges et al., 2011), which exhibit low basal friction related to lithology (marl, shale, coal and evaporite) and/or overpressure conditions (e.g. Cobbold and Rodrigues, 2007; Cobbold et al., 2009). These systems have been investigated in previous analogue studies that show the importance of the basal angle of the wedge and the shortening rate (e.g. Smit et al., 2003), as well as the presence of decollement levels in controlling coupling/decoupling processes (e.g. Couzens-Schultz et al., 2003; Massoli et al., 2006) and synkinematic sedimentation (Leturmy et al., 2000). The relationship between sedimentation and thrust geometry at the scale of a single structure has been studied using analogue modelling with one prekinematic ductile layer (Nalpas et al., 1999; Casas et al., 2001; Barrier et al., 2002; Nalpas et al.; 2003; Gestain et al., 2004; Barrier et al., 2013). However, only one study has been carried out at the scale of a single structure with two prekinematic ductile layers (Pichot and Nalpas, 2009), so there is a continuing debate about the vergence of the thrusts as well as the evolution of deformation at depth and at the surface in relation to mass transfer.

This study makes use of analogue modelling to investigate the formation and evolution of a compressive structure with a mechanical stratigraphy comprising three prekinematic decollement levels (ductile layers) accoding to (i) the amount of shortening and (ii) the synkinematic rate of mass transfer. The results of this experimental approach are then compared with a field example (the Subandean thrust-belt).

\section{Experimental procedure}

In this study, we apply the classical techniques used for brittle-ductile analogue modelling experiments developed by the Experimental Tectonics Laboratory of Géosciences Rennes (Université de Rennes 1, France). These techniques have been described in previous studies dealing 
with the use of a velocity discontinuity (VD; e.g. Malavieille, 1984; Balé, 1986; Ballard et al., 1987; Allemand et al., 1989), the use of silicone and sand (Faugère and Brun, 1984), and also various scaling issues (Davy and Cobbold, 1991; Weijermars et al., 1993). Brittle layers (pre- and synkinematic) are represented by dry Fontainebleau quartz sand, with an internal friction angle of $30-35^{\circ}$ (Krantz, 1991) and a density ( $\rho$ ) of approximately $1,500 \mathrm{~kg} / \mathrm{m}^{3}$. The weak ductile layers (e.g. salt, clay) are represented by i) pink silicone putty 70009 (Rhône Poulenc, France) with a viscosity $(\mu)$ of around $10^{4} \mathrm{~Pa} \cdot \mathrm{s}$ at $20^{\circ} \mathrm{C}$ and a density $(\rho)$ close to $1,400 \mathrm{~kg} / \mathrm{m}^{3}$, and ii) transparent silicone putty SGM 36 (Dow Corning, USA) with a viscosity ( $\mu$ ) of around $10^{4} \mathrm{~Pa} \cdot \mathrm{s}$ at $20^{\circ} \mathrm{C}$ and a density ( $\rho)$ close to $1,000 \mathrm{~kg} / \mathrm{m}^{3}$.

Silicone putty is commonly used to model salt, but it has also been used to model overpressured shales (e. g. Cohen and McClay, 1996; Wu and McClay, 2011). To take into account overpressures and pore fluids in decollement levels such as shales, physical modelling techniques have been developed using compressed air injected into beeswax microspheres (e.g. Cobbold and Castro, 1999; Cobbold et al., 2001; Mourgues and Cobbold, 2003; Zanella et al., 2014). The implementation of these techniques is complicated and remains impractical for experiments with three decollement levels, explaining why such an approach is not adopted here.

The experimental apparatus consists of a fixed wall screwed to a rigid and fixed basal plate, over which another wall fixed to a thin mobile basal plate is pushed at a constant rate (Fig. 1a). The two other sides are free and supported by sand to ensure uniform stresses. The displacement of the basal mobile plate induces a velocity discontinuity (VD) at its border, which localizes the deformation at the base of the model, (cf. Malavielle, 1984; Balé, 1986; Ballard, 1989). In our experiments, we use a VD to simulate only one structure, with the VD representing the zone localizing the deformation at the base of the model. The VD may represent either a basement fault, (e.g. Richard et al., 1991) or, in an imbricate thrust system, the tip line of a basal decollement (Boyer and Elliot, 1982; Casas et al., 2001). The experiment is set up in a $100 \times 60 \mathrm{~cm}$ sandbox, wide enough to allow the model to be cut into several vertical slices after each phase of deformation without border effects (see below).

To facilitate comparisons with natural examples such as the Bolivian Subandean fold and thrust belt, where several decollement levels are present, we set up experiments composed of a four-layer brittle-ductile system. The prekinematic pile consists of layers including, from bottom to top: $1 \mathrm{~cm}$ of purple silicone (lower decollement level); $1.2 \mathrm{~cm}$ of black and white sand; $0.8 \mathrm{~cm}$ of transparent silicone (middle decollement level); and $3 \mathrm{~cm}$ of black and white sand. The layer of black and white 
sand is composed of two $1.5 \mathrm{~cm}$ layers separated by a thin layer $(0.3 \mathrm{~cm})$ of silicone to facilitate flexural slip (Fig. 1a). The synkinematic pile is composed of blue and white sand layers of different thicknesses. To simulate synkinematic mass transfer, both sedimentation and erosion are simulated. Sedimentation is simulated using fresh sand (blue and white) that is continuously sprinkled manually onto the model during the shortening (e.g. Cobbold et al., 1993; Baby et al., 1995; Storti and McClay, 1995; Barrier et al., 2002). Erosion is simulated by removing sand with a vacuum cleaner. To define the amount of sedimentation, we use the dimensionless parameter $\mathrm{R}=\mathrm{Vs} / \mathrm{Vu}$, where $\mathrm{R}$ is the ratio between the rate of the sedimentation $(\mathrm{Vs})$ and the velocity of uplift of the structure ( Vu) (see Barrier et al., 2002; Pichot and Nalpas, 2009). To define the amount of erosion, we use a dimensionless parameter $\mathrm{E}=\mathrm{Ve} / \mathrm{Vu}$, where $\mathrm{E}$ is the ratio between the velocity of the erosion $(\mathrm{Ve})$ and the velocity of uplift of the structure $(\mathrm{Vu})$. The switchover between erosion and sedimentation corresponds to a base level in the stratigraphic sense (Posamentier et al., 1988; Posamentier and Vail, 1988), which implies that the system is being eroded above the base level, with transit occurring along this level and sedimentation below. Different sedimentation modes are chosen to represent the range of possible sedimentation rates within natural basins (Fig. 1b). In the first series of experiments, models are performed without sedimentation $(R=0)$, the second series with sedimentation and erosion $(\mathrm{R}=1 / 2$ and $\mathrm{E}=1 / 4)$, the third series with sedimentation alone $(\mathrm{R}=$ 1) and the fourth series with a high sedimentation/uplift ratio $(R=2)$. The variations of mass transfer between our experiments are comparable to different geographic positions in the Bolivian Subandean fold and thrust belt, ranging from the western zone with erosion, through the central foredeep with a high sedimentation rate to the eastern zone with a low sedimentation rate.

Table 1 presents the geometric and dynamic scaling of the models. The scale ratios for dimensions and stress between the models and nature are of the same order of magnitude $\left(10^{-5}\right)$, and the shortening rate is imposed by the scaling laws. A velocity of $1 \mathrm{~cm} / \mathrm{h}$ is used for displacement of the piston, mobile basal plate and wall, along with the associated velocity discontinuity (VD).

Photographs of the model surface are taken at regular time intervals (every $15 \mathrm{~min}$ ) to observe the development of the structure. Sand layers are made up of various colours; black and white for the prekinematic layers, and blue and white for the synkinematic layers (the colour of the sand does not modify its behaviour). After deformation, the internal structures and their time-evolution are observed in a series of cross-sections cut parallel to the compression direction and perpendicular to the VD. The experiments are conducted in three steps of shortening: i) compression of $5 \mathrm{~cm}$; ii) compression of $7.5 \mathrm{~cm}$; and iii) compression of $10 \mathrm{~cm}$. All the cross-sections extracted after each 
step are taken at a distance of at least $5 \mathrm{~cm}$ from the lateral border of the model, in order to avoid boundary effects. The deformation is not affected by stopping between steps. This is verified by an experiment in which $10 \mathrm{~cm}$ of shortening in one step yields the same amount of deformation as the experiment performed in 3 shortening steps. Although a total of twenty experiments were performed to test the reproducibility (denoted Bode 1 to Bode 20), only the results of four experiments are presented here.

To simplify the description of the silicone/sand pile of the model, we use the following terminology (Fig. 2). From bottom to top, the prekinematic layers are called: lower silicone layer; lower sand layer; middle silicone layer; middle sand layer; upper silicone layer; upper sand layer. The layers added during the experiment are termed synkinematic sand layers. The thrusts are named according to the sand layers affected and their geometry in relation to the VD inducing shear displacement (Ballard, 1989). For example, a synthetic thrust occurs when the hanging wall moves in a direction opposite to the movement of the mobile plate, and an antithetic thrust is characterized by the hanging wall moving in the same direction as the mobile plate. Therefore, as shown in Figure 2, the thrusts are referred to as follows, from bottom to top: lower synthetic thrust; middle antithetic thrust; upper synthetic thrust. The faults are colour coded to highlight the movement of the faults for each step of deformation (Fig. 3). The forward or backward propagation of the deformation is defined with respect to the previous structure considered (Fig. 2).

\section{Results of analogue modelling experiments}

\subsection{Shortening without sedimentation, $R=0$ (Fig. $3 a)$}

The main feature observed in this experiment is the synthetic vergence of all thrusts, associated with a forward propagation of the deformation.

More precisely:

- After $5 \mathrm{~cm}$ of shortening (Fig. 3a1), the lower and middle sand layers are affected by synthetic thrusts generating penetration of the lower and middle sand layers into the middle and upper silicone layers, respectively. The upper sand layer is affected by a synthetic thrust with a very shallow dip. 
- After $7.5 \mathrm{~cm}$ of shortening (Fig. 3a2), the anticline in the lower sand layer is amplified and associated with an accumulation of silicone forming a ridge in the lower silicone layer near the VD. The lower and middle synthetic thrusts grow in amplitude and are rotated anticlockwise. The upper synthetic thrust is still active, and a pop-up structure develops in front of the thrust (in yellow in Fig. 3a2).

- After $10 \mathrm{~cm}$ of shortening (Fig. 3a3), the lower and middle synthetic thrusts have undergone anticlockwise rotation and become no longer active. In addition, a new lower synthetic thrust develops (in yellow in Fig. 3a3). The upper synthetic thrust and the associated pop-up structure are still active. The layers are affected by an amplification of the folding.

\subsection{Shortening with synkinematic sedimentation and erosion, $R=1 / 2, E=1 / 4$ (Fig. 3b)}

The main feature of this experiment is the change in vergence of the middle and upper antithetic thrusts after $10 \mathrm{~cm}$ of shortening.

More precisely:

- After $5 \mathrm{~cm}$ of shortening (Fig. 3b1), the lower sand layer is affected by a synthetic thrust of flat geometry that penetrates the middle silicone layer. The middle and upper sand layers are affected by an antithetic thrust. Firstly, the middle antithetic thrust penetrates slightly into the upper silicone layer, and then, while showing a steeper dip, it connects up with the upper antithetic thrust. The upper sand layer is slightly eroded on the crest of the ramp anticline. The synkinematic layers show onlap geometry on the hanging wall of the upper thrust, and toplap geometry below the base of the thrust in the footwall.

- After $7.5 \mathrm{~cm}$ of shortening (Fig. 3b2), the deformation is similar to that observed for $5 \mathrm{~cm}$ of shortening with the same synthetic and antithetic thrusts. The lower synthetic thrust shows a large penetration into the middle silicone layer. An amplification of the the middle and upper antithetic thrusts induces more uplift and erosion on the crest of the ramp anticline in the upper sand layer. The synkinematic layers show the same overall geometry with increasing deformation.

- After $10 \mathrm{~cm}$ of shortening (Fig. 3b3), a change in the vergence of the deformation is observed. The lower synthetic thrust penetrates deeply into the middle silicone layer, while an incipient lower antithetic thrust is developed (in yellow in Fig. 3b3). The lower synthetic thrust is deformed, in 
relation to a thickening of the lower silicone layer near the VD. New middle and upper synthetic thrusts cut the previous middle and upper antithetic thrusts. The previous middle and upper antithetic thrusts are slightly rotated clockwise and displaced passively on the hanging wall of the newly formed middle and upper synthetic thrusts. The synkinematic layers deposited during the growth of these synthetic thrusts show onlap geometry on their hanging wall, thus sealing the previous antithetic thrust. These layers also show toplap geometry below the base of the synthetic thrust in the footwall.

\subsection{Shortening with synkinematic sedimentation, $R=1$ (Fig. 3c)}

The main feature of this experiment is that all the sand layers are affected by thrusts of opposite vergence developing a typical fish-tail structure.

More precisely:

- After $5 \mathrm{~cm}$ of shortening (Fig. 3c1), the lower sand layer is affected by a lower synthetic thrust that penetrates the middle silicone layer. The middle sand layer is affected by a middle antithetic thrust that penetrates into the upper silicone layer. The upper sand layer is affected by an upper synthetic steeply dipping thrust with an incipient upper antithetic fault in its hanging wall. This faulting pattern with opposing vergence is typical of a fish-tail structure. The synkinematic layers show onlap geometry on the hanging wall of the upper thrust, and toplap geometry below the base of the thrust in the footwall.

- After $7.5 \mathrm{~cm}$ of shortening (Fig. 3c2), the lower antithetic thrust penetrates deeply into the middle silicone layer. The middle antithetic thrust has ceased growing and a new steeply dipping antithetic thrust is formed cutting the upper sand layer and affecting the synkinematic layers. The upper synthetic thrust ceases and a new upper antithetic thrust cuts the previous synthetic thrust and synkinematic layers. The synkinematic layers show onlap geometry in the direction of the anticline crest.

- After $10 \mathrm{~cm}$ of shortening (Fig. 3c3), the lower synthetic thrust penetrates deeply into the middle silicone layer without anticline growth. The growth of the middle antithetic thrust continues until it is cut by a new synthetic thrust. This thrust has variable dip, the lower part being nearly horizontal, and the upper part steeply dipping (in yellow in Fig. 3c3). The vertical amplification of the 
structures in the centre of the model is associated with a verticalization of the prekinematic layers. The synkinematic layers show onlap geometry in the direction of the anticline crest.

\subsection{Shortening with synkinematic sedimentation, $R=2$ (Fig. 3d)}

The main feature of this experiment is that all sand layers are affected by thrusts with opposing vergence, thus developing a typical fish-tail structure. Finally, at the end of the shortening, the deformation shows a double vergence.

More precisely:

- After $5 \mathrm{~cm}$ of shortening (Fig. 3d1), the lower sand layer is affected by a lower synthetic thrust that penetrates into the middle silicone layer. The middle sand layer is affected by a middle antithetic thrust that penetrates into the upper silicone layer. The upper sand layer is affected by a major upper synthetic thrust and an incipient antithetic thrust. Although such a fault pattern with opposing vergence is typical of a fish-tail structure, there is less folding and uplift in this case than previously observed (Fig. 3c1). The synkinematic layers show a progressive decrease in the thickness of the hanging wall in the direction of the upper synthetic thrust (in green in Fig. 3d1), and a nearly constant thickness on its footwall. The thrusts near the piston in the middle and upper sand layers are due to boundary effects at the beginning of the experiment (in grey in Fig. 3d).

- After $7.5 \mathrm{~cm}$ of shortening (Fig. 3d2), the deformation is similar to that observed for $5 \mathrm{~cm}$ of shortening. The lower synthetic thrust shows deep penetration into the middle silicone layer. The growth of the middle antithetic thrust continues and an incipient middle antithetic fault is formed. The upper synthetic and antithetic thrusts are still active, associated with the development of a new incipient antithetic thrust. The synkinematic layers show the same overall geometry as before.

- After $10 \mathrm{~cm}$ of shortening (Fig. 3d3), the lower synthetic thrust penetrates deeply into the middle silicone layer, and the lower sand layer is also affected by an new anthitetic thrust. The middle antithetic thrust is cut by a middle synthetic thrust. The upper sand layer and the synkinematic layers are affected by a synthetic and an anthitetic thrust, as well as a new synthetic thrust. These associated faults induce a double vergence in the deformation, and the synkinematic layers display a relatively constant thickness.

\subsection{Time-evolution of structure uplift (Fig. 4)}


The time-evolution of the anticline crest uplift, which is associated with the thrusts, affects the lower and upper sand layers in completely different ways depending on the $\mathrm{R}$ ratio. The maximum uplift of the upper sand layer anticline is observed when the sedimentation rate is equal to the uplift velocity $(R=1)$, and the minimum uplift is observed when there is no sedimentation $(R=0)$. On the contrary, the maximum uplift of the lower sand layer structure is observed when there is no sedimentation $(\mathrm{R}=0)$ and minimum uplift occurs when the sedimentation rate is equal to or greater than the velocity of uplift ( $R=2$ or 1 ). It is important to note that the amplitude of the uplift is nearly the same (around $4 \mathrm{~cm}$ ) for the lower and upper sand structure when there is no sedimentation $(R=0)$. When the sedimentation rate is equal to the uplift velocity $(R=1)$, the amplitude of the uplift in the upper sand layer is three times that of the lower sand layer (around 7.5 $\mathrm{cm}$ and $2.5 \mathrm{~cm}$, respectively). Note that, when the sedimentation/uplift ratio is intermediate between these two cases ( $\mathrm{R}=1 / 2, \mathrm{E}=1 / 4)$, the amplitude of the uplift is also intermediate. When the sedimentation rate is double the uplift velocity $(\mathrm{R}=2)$, the uplift of the lower sand layer structure decreases to its minimum amplitude, while the uplift of the upper sand layer structure is lower than for $\mathrm{R}=1$ and $\mathrm{R}=1 / 2$, with $\mathrm{E}=1 / 4$, as noted by Barrier et al. (2013).

\section{Discussion}

\subsection{Influence of initial mechanical stratigraphy}

The initial mechanical stratigraphy is characterized by the presence of interbedded silicone layers and sand layers that allow decoupling between the sand layers.

Firstly, a typical flat lower thrust is developed because the lower sand layers penetrate into the middle detachment level (see Fig. 5 for main features of experiments after $10 \mathrm{~cm}$ of shortening). The geometry of the upper reverse fault is dependent on the sedimentation/uplift ratio (e.g. Pichot and Nalpas, 2009; Barrier et al., 2013), and shows a maximum dip when $\mathrm{R}=1$ or 2 (Fig. 3a1, b1, $\mathrm{c1}$, d1 and 5, see $\alpha<\beta$ ). Secondly, two superposed thrusts with opposite vergence create a fish-tail structure when the interbedded silicone layer acts as a decollement level (Figs. 3c1 and d1). These fish-tail structures are created only when sedimentation occurs during deformation (for $\mathrm{R}=1$ and 2). In the experiment with low ratios of sedimentation and erosion with respect to uplift of the structure $(\mathrm{R}=1 / 2, \mathrm{E}=1 / 4)$, a fish-tail structure is only present between the lower and middle sand layers (Fig. 3b). In the experiment without sedimentation, no fish-tail structures are created (Fig. 3a). Therefore, the presence of decollement levels is a necessary but insufficient condition to 
produce such fish-tail structures. Thirdly, the presence of a decollement level allows the deformation to propagate forward of the main upper structure (Figs. $3 \mathrm{a} 2$ and a3), provided there is no sedimentation. Finally, we suggest it is necessary to have an initial mechanical stratigraphy with several decollement levels to create specific features such as fish-tail structures and forward propagation of the deformation. However, the presence of several decollement levels is insufficient to explain the geometric evolution and variability of the structures.

\subsection{Influence of shortening}

Increasing shortening induces major deformation in the model, creating structures with a marked uplift (Fig. 4), and an increase in the thrust throw. Firstly, during the increase in the amount of shortening, two possible trends of development can be observed. When there is no sedimentation, the model develops an overall asymmetric shape (Figs. 3a1 to a3). Alternatively, in the experiment with sedimentation, the shape of the model evolves from asymmetric to doubly vergent (Figs. 3b3, c1 to $\mathrm{c} 3$, and d1 to d3). Secondly, increased shortening enhances the penetration of thrusts into the overlying silicone layer. Thirdly, although increased shortening allows the deformation to propagate forward (Figs. $3 \mathrm{a} 2$ and a3), this can only take place in the absence of sedimentation. Finally, we suggest that increased shortening is necessary to ensure an evolution in the overall shape of the model, but is not sufficient to explain why this evolution is possible.

\subsection{Influence of synkinematic sedimentation}

The geometry of the structure is highly dependent on the sedimentation/uplift ratio (Figs. 3 and 5).

Without sedimentation, the geometry of structures is similar in the lower, middle and upper layers insofar as they display the same synthetic vergence. Any increase in the shortening is accommodated by a forward propagation of the deformation (Figs. 3a and 5a). By contrast, with sedimentation, the geometry of the structures is different in the lower, middle and upper layers with different vergence. Also there is no propagation of the deformation during shortening, and all the structures are stacked above the VD (Figs. 3b, c, d and 5b, c).

With sedimentation, the geometry of the faults shows a fish-tail structure for the lower and middle sand layers when $R=1 / 2$ with ongoing erosion $(E=1 / 4$ ), and for all layers when $R=1$ and 2 (Figs. 3 and 5). This implies that more fish-tail structures are developed when the sedimentation rate is higher. Such an effect may be related to an increase in normal stress induced by the synkinematic 
layers, which increases the strength of the interbedded sand layers. In this way, the differential strength between the sand and silicone layers increases, thereby making it easier for the sand layers to penetrate the silicone layers.

During deformation, the overall shape of the model changes from asymmetric to doubly vergent, with an increase in shortening that is only observed with synkinematic sedimentation. With an increase in sedimentation with respect to uplift ( $R=1$ to 2 ), the model shows an increasingly prominent doubly vergent shape.

In agreement with previous experimental studies (e.g. Tondji-Biyo, 1995; Nalpas et al., 1999; Barrier et al., 2002; Nalpas et al., 2003; Pichot and Nalpas, 2009; Barrier et al., 2013), synkinematic sedimentation strongly influences the uplift of compressive growth structures. When $\mathrm{R}=0$, the effect of shortening in the lower and upper layers is the same, being associated with forward propagation of the deformation without major uplift. The maximum uplift is found in the experiment with $\mathrm{R}=1$ (Figs. 3, 4 and 5), but it is noteworthy that, when the uplift of the upper structure increases, the lower structure undergoes less uplift (Fig. 4). When $\mathrm{R}=1$, the effect of shortening in the lower and upper layers is different: the lower layer propagates horizontally, while the upper layer grows vertically. The uplift of the lower structure is inhibited by the weight of the sediments, which explains why there is minor uplift for $\mathrm{R}=2$, and major uplift for $\mathrm{R}=0$.

\section{Comparison with natural examples}

The structural style of the Bolivian Subandean foothills is characterized by elongated N-S trending tight folds in the Chaco Basin (Figs. 6a and b). The geometry of the fold and thrust belt is mainly controlled by lithology and the presence of three main potential decollement levels (Baby et al, 1989; Baby et al, 1992; Moretti et al., 1996; Giraudo and Limachi, 2001; Moretti et al., 2002). The basal decollement level is located in the Kirusillas shales (Late Silurian). The middle decollement levels are identified at Icla (Early Devonian) and Los Monos (Late Devonian), where potential decollement is controlled by the clay content of the formations involved. The decollement levels partly disconnect the deformation observed at the surface (Tertiary to Lower Carboniferous series) from that occurring at depth (Devonian sandstones, Huamampampa, Fig. 6c). The upper decollement level, which is the thinnest, is located in the Ipaguazu Formation, which is composed of gypsum and shales (Triassic). Fluid overpressure in maturing source rocks may have an effect on detachments and the propagation of deformation in compressive systems (Cobbold and Rodrigues, 
2007; Cobbold et al., 2009), but we do not discuss this possibility here because we have only analysed the geometry of isolated structures.

The Chaco Basin is a classical foreland basin in a retro arc position (Uba et al., 2005 and 2006). Tertiary sedimentation is regarded as taking place in a foreland basin sequence during the Late Oligocene to Early Miocene. The base of this sequence is represented by the unconformable fluvial Petaca Formation (Late Oligocene to Early Miocene), which may be attributed to sedimentation in a forebulge-backbulge depocentre. The overlying Yecua Formation (Middle to Late Miocene) corresponds to the onset of active deformation and large-scale subsidence in response to thrust-belt loading on a regional scale (distal foredeep). The overlying Tariquia Formation (Late Miocene) is concomitant with the onset of deposition of Andean derived sediment in the medial-foredeep depocentre. In our study area, eastward from the Incahuasi structure (Fig. 6b), these formations may be considered as of relatively constant thickness and are thus pre-tectonic. In the western part of our study area, westward from the Incahuasi structure (Fig. 6b), these formations are of variable thickness and may be considered as syn-tectonic.

The Guandacay Formation (Late Miocene to Early Pliocene) and Emborozu Formation (Late Pliocene to Pleistocene) are coeval with the propagation of the deformation front in the Subandean Zone and thus represent true syntectonic deposits associated with the emplacement of the folds and thrusts in our studied area (Incahuasi structure). Their thickness can vary between 1000 - $3500 \mathrm{~m}$. The age of the Guandacay Formation corresponds to the peak of shortening calculated by Moretti et al. (1996).

As hydrocarbon exploration in Bolivia targets a deep-seated reservoir below the main upper decollement (Devonian Los Monos Formation), some of these N-S trending tight folds have been drilled and some seismic data exists. The quality of seismic data in the Subandean Zone is poor and this hinders clear imaging of the deep-seated structures. Therefore, it is difficult to interpret the seismic data, which often give rise to misleading interpretations. Among the folds in the area, the Incahuasi anticline shows some interesting features. Three exploration wells drilled on the anticline axis confirm that the top of the Huamampampa Formation is offset by at least $1 \mathrm{~km}$ to the east with respect to the surface anticline axial plane (Fig. 7) as evidenced by sampling and dipmeter data acquired during drilling. The surface Incahuasi structure is overturned towards the west and shows a vergence contrary to that of most other folds in the Subandean Zone (Fig. 6). The main backthrust that accommodates this overfolding is rooted in the basal shale of the Los Monos Formation, close 
to the interface with the Huamampampa quartzites. The dipmeter data in wells confirm the fact that the deep-seated thrust system affecting the Huamampampa Formation also faces towards the west (hinterland). Geological cross-sections constrained by field and several wells data confirm that the Incahuasi thrust, facing towards the east, has been passively rotated by the emplacement of the backthrust (Figs. 6 and 7), which postdates the Incahuasi thrust, in the same way as reproduced by analogue modelling (Figs. 3b).

A comparison between the Incahuasi subsurface data and the analogue experiments (inverted crosssection of the model of figure 3b3) allows us to propose an interpretation of the Incahuasi structure in a cross-section showing the evolution of the thrust in time and space (Fig. 7). The overall evolution corresponds to an inversion of the vergence of the thrust. The first fault propagation fold is cut and displaced passively along with the hanging wall of the newly formed thrust fault. Therefore, the change in the vergence of the Incahuasi fold may be explained by the influence of sedimentation rate. Figure 7 compares the subsurface data, their interpretation and the interpreted cross-section of a model, showing the positive contribution of analogue modelling to an improved interpretation of the seismic lines.

A comparison can also be made between the experimental results and subsurface data for the whole cross-section of the Subandean system (Fig. 6b). We propose that, in the eastern part, the structures of Camiri, Carohuaycho Los Huesos, Caipipendi and Charagua are characterized by major asymmetric geometries and propagation of deformation in front of the thrust, which is characteristic of the experiment with low sedimentation rate (Figs. 3a and 5a). The central zone corresponding to the Incahuasi structure shows a drastic change in vergence direction, which is comparable to the experiment with a medium rate of sedimentation (Figs. $3 \mathrm{~b}$ and $5 \mathrm{~b}$ ). The western structures of Ilinchunpa and Inau are characterized by a double vergence and vertical propagation of the deformation, corresponding to the experiment with high sedimentation rate (Figs. 3c3, d3; and 5c). Thus, this lateral variation in the structures (see also Baby et al., 1992; Moretti et al., 1996; Giraudo and Limachi, 2001; Moretti et al., 2002) is consistent with an increase in shortening from east to west and a decrease in rate of sedimentation from the hinterland toward the foreland.

\section{Conclusions}

The experimental results presented here suggest that: 
a - The initial mechanical stratigraphy and the presence of several decollement levels are necessary conditions for the creation of specific features related to decoupling between sand layers, such as fish-tail structures and the propagation of deformation. However, these conditions alone cannot explain the evolution and variability in the geometries of the structures.

b - The final geometry of the structure seems to be highly dependent on the sedimentation/uplift ratio, $\mathrm{R}$. When $\mathrm{R}=0$ (no sedimentation), the deformation propagates forward with an overall asymmetric shape. When $R=1 / 2$ or 1 (low sedimentation rate), the deformation increases vertically with steeply dipping faults, and the vergence of the structure changes with the development of a thrust with opposite vergence. When $\mathrm{R}=2$ (high sedimentation rate), the deformation creates a pattern of doubly vergent structures at the surface and at depth, with the development of a conjugate structure and associated uplift.

$\mathrm{c}$ - The expression of deformation in the brittle layers below the upper decollement levels is different compared with layers above the upper decollement levels, and depends on decoupling and sedimentation rate. With low mass transfer (low sedimentation rate), the lower and upper brittle layers are deformed in the same way with the same amount of uplift. On the other hand, with high mass transfer (high sedimentation rate), the lower brittle layers show much less uplift than the upper brittle layers.

d - Application of the analogue modelling results to the Subandean compressive system suggests that the west to east evolution of the structures in the thrust and fold belt (from doubly vergent with several faults and large uplift to asymmetric with a single major fault) is related to the variation in the amount of shortening and sedimentation rate.

e - Seismic lines have low resolution in compressive systems with intense deformation and steeply dipping layers. Therefore, in such a context, analogue modelling can be a useful tool for exploring the geometric possibilities in relation to the evolution of structures, allowing us to improve the interpretation of seismic lines.

\section{Acknowledgements:}

We acknowledge Total for financial support. Special thanks are due to J.-J. Kermarrec for his 
valuable technical assistance and availability. We thank Sara Mullin, Noelle Odling and Mike Carpenter for their editing of the English style. Finally, we are grateful to P. Cobbold and C. Gomes for their detailed review, constructive comments and suggestions that helped us improve an early version of the manuscript.

\section{References}

Allemand, P., Brun, J.-P., Davy, P., Van Den Driessche, J., 1989. Symétrie et asymétrie des rifts et mécanismes d'amincissement de la lithosphère. Bulletin de la Société Géologique de France 3, 445-451.

Baby, P., Hérail, G., Lopez, J.M., Lopez, O., Oller, J., Pareja, J., Sempere, T., Tufiño, D., 1989. Structure de la Zone Subandine de Bolivie: infuence de la géométrie des séries sédimentaires antéorogéniques sur la propagation des chevauchements. Comptes Rendus de l'Académie des Sciences, 309, 1717-1722.

Baby, P., Hérail, G., Salinas, R., Sempere, T. 1992. Geometric and kinematic evolution of passive roof duplexes deduced from cross section balancing: example from the foreland thrust system of the southern Bolivian Subandean Zone. Tectonics, 11, 523-536.

Baby, P., Colletta, B., Zubietta, D., 1995. Etude géométrique et expérimentale d'un bassin transporté: exemple du synclinorium de l'Alto Beni (Andes centrales). Bulletin de la Société Géologique de France, $166,797-811$.

Balé, P., 1986. Tectonique cadomienne en Bretagne nord. Interaction décrochement chevauchement : champs de déformation et modélisations expérimentales. Ph.D. thesis, Université de Rennes 1.

Ballard, J.F., Brun, J.P., Van Den Driessche, J., Allemand, P., 1987. Propagation des chevauchements audessus des zones de décollement : Modèles expérimentaux. Comptes Rendus de l'Académie des Science de Paris, Série IIA 305, 1249-1253.

Ballard, J.F., 1989. Approche géologique et mécanique des décollements dans la croûte supérieure. Ph.D. thesis, Université de Rennes 1.

Barrier, L., Nalpas, T., Gapais, D., Proust, J.-N., Casas, A., Bourquin, S., 2002. Influence of syntectonic sedimentation on thrusts geometry. Field examples from the Iberian Chain (Spain) and analogue modeling. Sedimentary Geology 146, 91-104. 
Barrier, L., Nalpas, T., Gapais, D., Proust, J.-N., 2013. Impact of synkinematic sedimentation on the geometry and dynamics of compressive growth structures: Insights from analogue modelling. Tectonophysics 608, 737-752.

Boyer, S.E., Elliott, D., 1982. Thrust systems. American Association of Petroleum Geologists Bulletin 66, 1196-1230.

Casas, A.M., Gapais, D., Nalpas, T., Besnard, K. Roman Berdiel, T., 2001. Analogue models of transpressive systems. Journal of Structural Geology 23, 733-743.

Cobbold, P.R., Davy, P., Gapais, D., Rossello, E.A., Sadybakasov, E., Thomas, J.C., Tondji Biyo, J.J., de Urreiztieta, M., 1993. Sedimentary basins and crustal thickening. Sedimentary Geology, 86, 77-89.

Cobbold, P.R., Castro, L., 1999. Fluid pressure and effective stress in sandbox models. Tectonophysics 301, $1-19$.

Cobbold, P.R., Durand, S., Mourgues, R., 2001. Sandbox modelling of thrust wedges with fluid-assisted detachments. Tectonophysics 334, 245-258.

Cobbold, P.R., Rodrigues, N., 2007. Seepage forces, important factors in the formation of horizontal hydraulic fractures and bedding-parallel fibrous veins ("beef" and "cone-in-cone"). Geofluids 7, 313 332.

Cobbold, P.R., Clarke, B.J., Løseth, H., 2009. Structural consequences of fluid overpressure and seepage forces in the outer thrust belt of the Niger Delta. Petroleum Geoscience 15, 3-15.

Cohen H.A., McClay K.R.,1996. Sedimentation and shale tectonics of the northwestern Niger Delta front. Marine and Petroleum Geology 13, 313-328.

Couzens-Schultz, B., Vendeville, B. Wiltschko, D., 2003. Duplex style and triangle zone formation: insights from physical modeling. Journal of Structural Geology 25, 1623-1644.

Davy, P., Cobbold, P. R., 1991. Experiments on shortening of a 4-layer model of continental lithosphere. Tectonophysics 188, 1-25.

Dunn, J. F., Hartshorn, K. G., Hartshorn, P. W., 1995. Structural styles and hydro- carbon potential of the sub-Andean thrust belt of southern Bolivia. In: Tankard, A. J., Suárez Soruco, R., Welsink, H. J. (Eds.), Petroleum basins of South America: AAPG Memoir 62, 523-543. 
Faugère, E. Brun, J.-P., 1984. Modélisation expérimentale de la distension continentale. Comptes-Rendus de l'Académie des Sciences 299, 365-370.

Gestain, V., Nalpas, T., Rouby, D., Barrier, L., 2004. Rôle des niveaux incompétents syncinématiques sur l'évolution des structures chevauchantes. Bulletin de la Société Géologique de France 175, 351-359.

Giraudo R., Limachi R., 2001. Pre-Silurian control in the genesis of the central and southern Bolivian fold belt. Journal of South American Earth Science 14, 665-680.

Horton, B.K., 1999. Erosional control on the geometry and kinematics of thrust belt development in the central Andes. Tectonics 18, 1292-1304.

Krantz, R. W., 1991. Measurements of friction coefficients and cohesion for faulting and fault reactivation in laboratory models using sand and sand mixtures. Tectonophysics 188, 203-207.

Labaume, P., Moretti, I., 2001. Diagenesis-dependence of cataclastic thrust fault zone sealing in sandstones. Example from the Bolivian Sub-Andean Zone. Journal of Structural Geology 21, 1659-1675.

Leturmy, P., Mugnier, J.L., Vinour, P., Baby, P., Colletta, B., Chabron, E., 2000. Piggyback basin development above a thin-skinned thrust belt with two detachment levels as a function of interactions between tectonic and superficial mass transfer: the case of the Subandean Zone (Bolivia).Tectonophysics 320, 45-67.

Malavieille, J. 1984. Modélisation expérimentale des chevauchements imbriqués: application aux chaînes de montagnes, Bulletin de la Société Géologique de France 26, 129-138.

Massoli, D., Koyi, H. A., Barchi, M. R., 2006. Structural evolution of a fold and thrust belt generated by multiple décollements: analogue models and natural examples from the Northern Apennines (Italy). Journal of Structural Geology 28, 185-199.

Moretti, I., Baby. P., Mendez, E., Zubieta, D., 1996. Hydrocarbon generation in relation to thrusting in the Sub Andean zone from 18 to 22 degrees S, Bolivia. Petroleum Geoscience 2, 17-28.

Moretti, I., Labaume, P., Sheppard, S.M.F., Boulègue, J., 2002. Compartmentalisation of fluid migration pathways in the sub-Andean Zone, Bolivia. Tectonophysics 348, 5-24.

Mourgues, R., Cobbold, P.R., 2003. Some tectonic consequences of fluid overpressures and seepage forces as demonstrated by sandbox modelling. Tectonophysics $376,75-97$. 
Nalpas, T., Györfi, I., Guillocheau, F., Lafont, F., Homewood, P., 1999. Influence de la charge sédimentaire sur le développement d'anticlinaux synsédimentaires. Modélisation analogique et exemples de terrain (Bordure sud du bassin de Jaca). Bulletin de la Société Géologique de France 170, 733-740.

Nalpas, T., Gapais, D., Verges, J., Barrier, L., Gestain, G., Leroux, G., Rouby, D., Kermarrec, J.J., 2003. Effects of rate and nature of synkinematic sedimentation on the growth of compressive structures constrained by analogue models and field examples. Geological Society of London Special Publication 208, 307-319.

Pichot, T., Nalpas, T., 2009. Influence of synkinematic sedimentation in a thrust system with two decollement levels; analogue modeling. Tectonophysics 473, 466-475.

Posamentier, H.W., Jervey, M.T., Vail, P.R., 1988. Eustatic controls on clastic deposition I - conceptual framework. In: Wilgus, C.K., Hastings, B.S., Kendall, C.G.St.C., Posamentier, H.W., Ross, C.A., Van Wagoner, J.C. (Eds.), Sea Level Changes - An Integrated Approach. Special Publication, vol. 42. Society of Economic Paleontologists and Mineralogists (SEPM), 110-124.

Posamentier, H.W., Vail, P.R., 1988. Eustatic controls on clasti deposition II - sequence and systems tract models. In: Wilgus, C.K. Hastings, B.S., Posamentier, H.W., Van Wagoner, J., Ross, C.A. Kendall, C.G.St.C. (Eds.), Sea-level Changes - An Integrated Approach, vol. 42. SEPM Publication, 125-154.

Richard, P., Mocquet, B., Cobbold, P.R., 1991. Experiments on simultaneous faulting and folding above a basement wrench fault. Tectonophysics 188, 133-141.

Sepehr, M., Coscrove, J. W. Moieni, M. 2006. The impact of cover rock rheology on the style of folding in the Zagros fold-thrust belt. Tectonophysics 427, 265-81.

Smit, J.H.W., Brun, J.-P., Sokoutis, D., 2003. Deformation of brittle-ductile thrust wedges in experiments and nature. Journal of Geophysical Research 108, B10, 2480, doi: 10.1029/2002JB002190.

Storti, F., McClay, K., 1995. Influence of syntectonic sedimentation on thrust wedges in analogue models. Geology 23, 999-1002.

Tondji Biyo, J.J., 1995. Chevauchements et bassins compressifs. Influence de l'érosion et de la sédimentation. Mémoires de Géosciences Rennes.

Uba, C.E., Heubeck, C., Hulka, C., 2005. Facies analysis and basin architecture of the Neogene Subandean synorogenic wedge, southern Bolivia. Sedimentary Geology 180, 91-123. doi: 10.1016/j.sedgeo.2005.06.013. 
Uba, C.E., Heubeck, C., Hulka, C., 2006,.Evolution of the late Cenozoic Chaco foreland basin, southern Bolivia. Basin Research 18, 145-170, doi: 10.1111/j.1365-2117.2006.00291.x.

Verges, J., Goodarzi, M. G. H., Emami, H., Karpuz, R., Efstathiou, J., Gillespie, P., 2011. Multiple detachment folding in Pusht-e Kuh arc, Zagros: Role of mechanical stratigraphy. In: McClay, K., Shaw, J., Suppe, J. (Eds.), Thrust fault-related folding: AAPG Memoir 94, 69-94.

Weijermars, R., Jackson, M.P.A., Vendeville, B., 1993. Rheological and tectonic modeling of salt provinces. Tectonophysics 217, 143-174.

Wu, J.E., McClay, K.R., 2011. Two-dimensional analog modelling of fold and thrust belts: Dynamic interactions with syncontractional sedimentation and erosion. In: K. McClay, J. Shaw, J. Suppe, (Eds.), Thrust fault-related folding: AAPG Memoir 94, 301-333.

YPFB-SERGEOMIN, 1996. Mapa geológico de Bolivia 1:1 000000.

Zanella, A., Cobbold, P.R., Le Carlier de Veslud, C., 2014. Physical modelling of chemical compaction, overpressure development, hydraulic fracturing and thrust detachments in organic-rich source rock Original Research. Marine and Petroleum Geology, Article In Press.

\section{Figure and Table captions}

Figure 1: (a) Experimental apparatus and (b) sketch of the homogeneous and local synkinematic sedimentation. $R$ is the ratio between the sedimentation rate, Vs, and the velocity of structure uplift, $V u(R=V s / V u$, see Barrier et al., 2002). E is the ratio between the erosion rate, Ve, and the velocity of structure uplift, $V u(E=V e / V u)$.

Figure 2: Cross-section showing the terminology used in the description of the experiments.

Figure 3: Cross-sections of experiments for 5, 7.5, $10 \mathrm{~cm}$ of shortening. al to a3: for $R=0$; $b 1$ to b3; for $R=1 / 2$ and $E=1 / 4 ;$ c 1 to c3: for $R=1$; $d 1$ to d3: for $R=2$. The colour coding used is green for a fault active only at the beginning of deformation, red for a fault active throughout deformation and yellow for a fault active at the end of deformation. "Bode" and "Repa" denote different experiments. 
542 Figure 4: Diagram showing time-evolution of uplift of the upper and lower structures during 543 compression.

544 Figure 5: Schematic cross-section of experiments after $10 \mathrm{~cm}$ of shortening showing the main 545 features of the structures.

546 Figure 6: (a) Geological map of Bolivia showing location of the interpreted seismic line (YPFB547 SERGEOMIN, 1996). (b) Cross-section of the Subandean fold and thrust belts across the Incahuasi 548 structure (using surface and subsurface data), the names correspond to the main structures. (c) 549 Stratigraphic column of the Bolivian Subandean Zone (Moretti et al., 2002), interpreted in terms of 550 mechanical stratigraphy, compared with structures obtained in the analogue experiments.

551 Figure 7: (a) Subsurface data (seismic line and well) for the Incahuasi structure. (b) Interpretation 552 of the Incahuasi structure (c) Inverted cross-section of experiment b after $10 \mathrm{~cm}$ of shortening (see 553 figure $3 b 3)$.

554 Table 1: Scaling of parameters between nature and models. $L, g, \rho, \mu, V, t$, and $\sigma$ represent the 555 length, acceleration due to gravity, density, viscosity, shortening rate, time and stress, respectively. 


\section{ACCEPTED MANUSCRIPT}

\begin{tabular}{cccccccc}
\hline & $\mathbf{L}$ & $\mathbf{g}$ & $\boldsymbol{\rho}$ & $\boldsymbol{\mu}$ & $\mathbf{V}$ & $\mathbf{t}$ & $\boldsymbol{\sigma}$ \\
& $(\mathrm{m})$ & $\left(\mathrm{m} / \mathrm{s}^{2}\right)$ & $\left(\mathrm{kg} / \mathrm{m}^{3}\right)$ & $(\mathrm{Pa} \cdot \mathrm{s})$ & $(\mathrm{m} / \mathrm{s})$ & $(\mathrm{s})$ & $(\mathrm{Pa})$ \\
\hline \hline Nature & $\begin{array}{c}1000 \\
(1 \mathrm{~km})\end{array}$ & 9.81 & 2300 & $2 \times 10^{17}$ & $\begin{array}{c}3.2 \times 10^{-10} \\
( \pm 1 \mathrm{~cm} / \mathrm{year})\end{array}$ & $\begin{array}{c}3.1 \times 10^{12} \\
(1 \mathrm{Ma})\end{array}$ & $2.2 \times 10^{7}$ \\
\hline Model & 0.01 & 9.81 & 1400 & $1.4 \times 10^{4}$ & $\begin{array}{c}2.7 \times 10^{-06} \\
(1 \mathrm{~cm} / \mathrm{h})\end{array}$ & $\begin{array}{c}3.6 \times 10^{3} \\
(10 \mathrm{~h})\end{array}$ & $1.3 \times 10^{2}$ \\
\hline $\begin{array}{c}\text { Model/nature } \\
\text { ratio }\end{array}$ & $10^{-05}$ & 1 & 0.6 & $7 \times 10^{-15}$ & $8.7 \times 10^{03}$ & $1.1 \times 10^{-09}$ & $6.1 \times 10^{6}$ \\
\hline
\end{tabular}



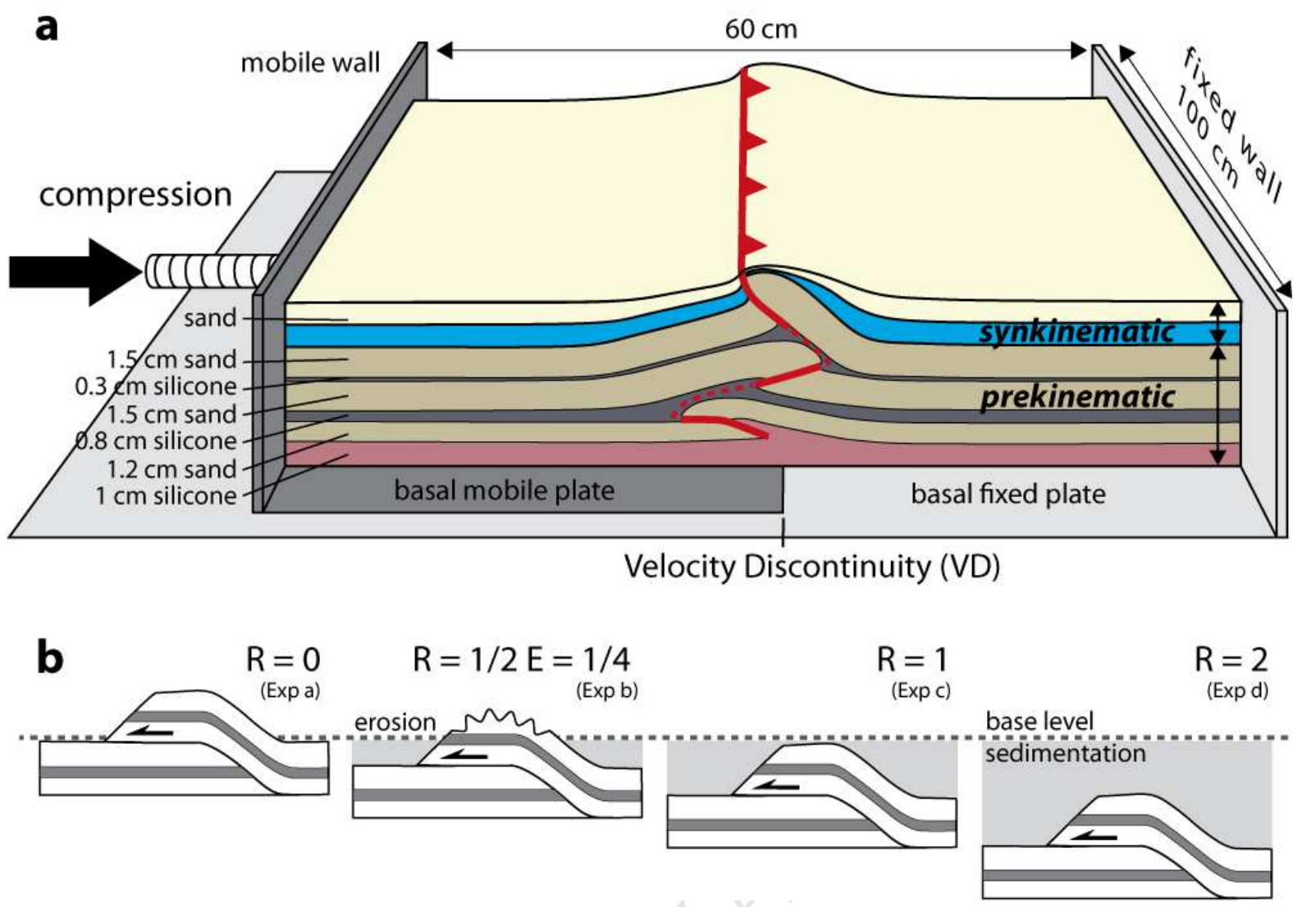


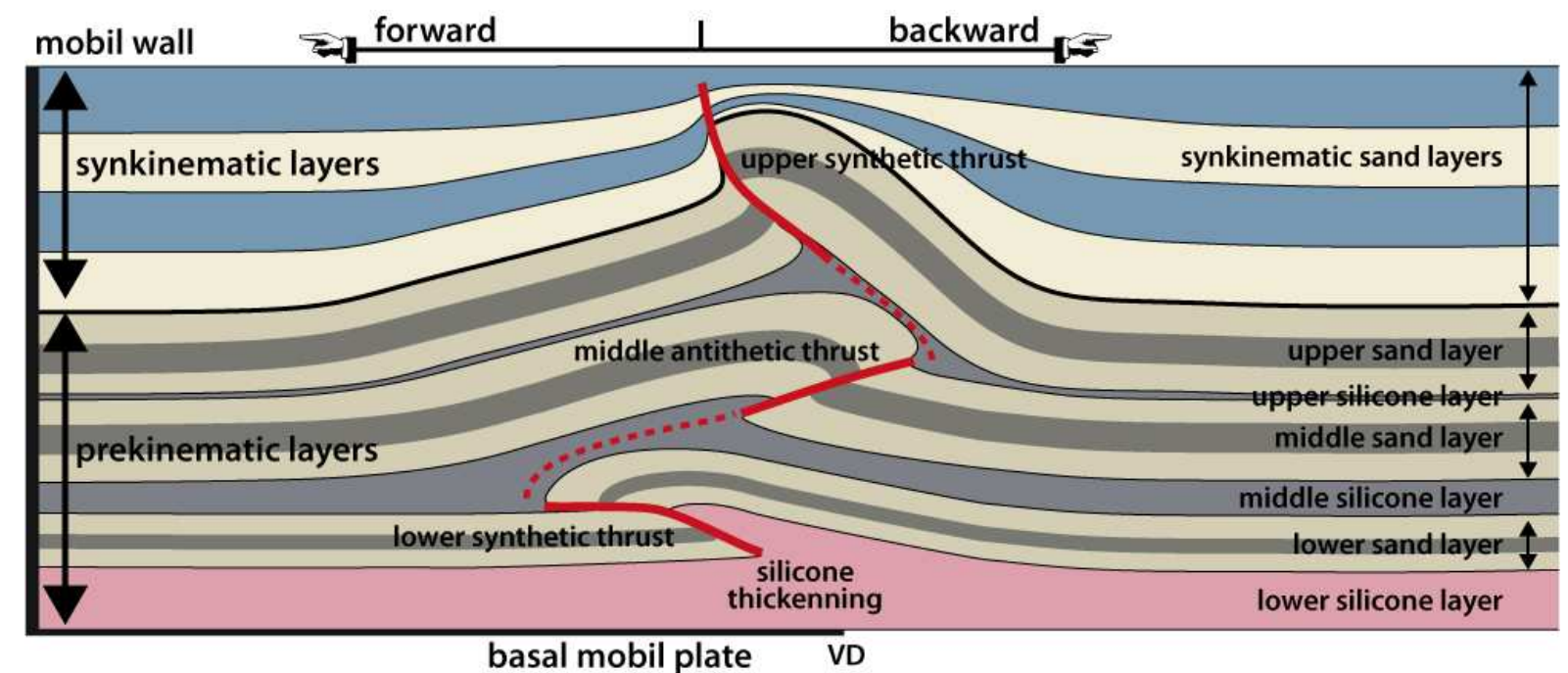

basal mobil plate vD 


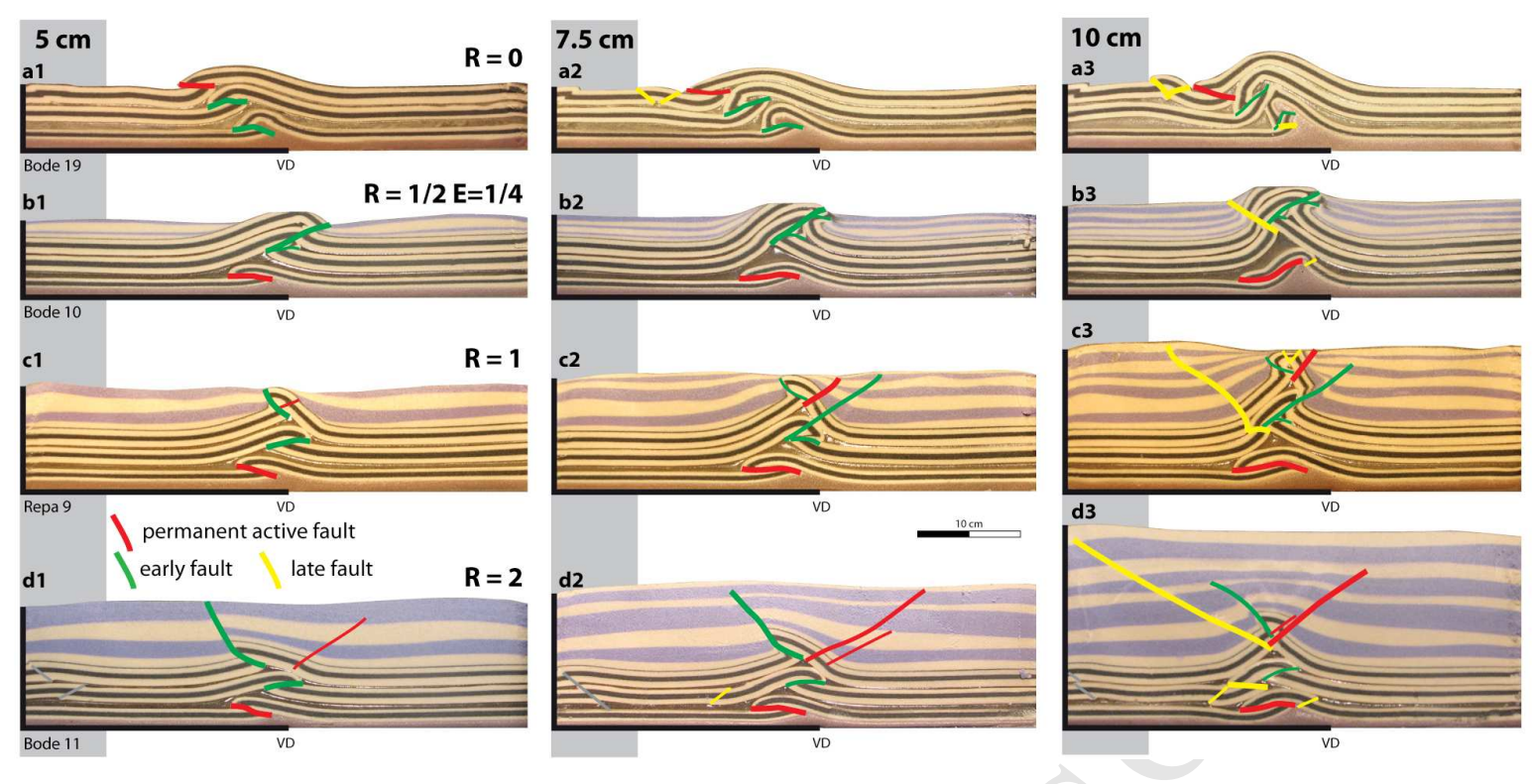




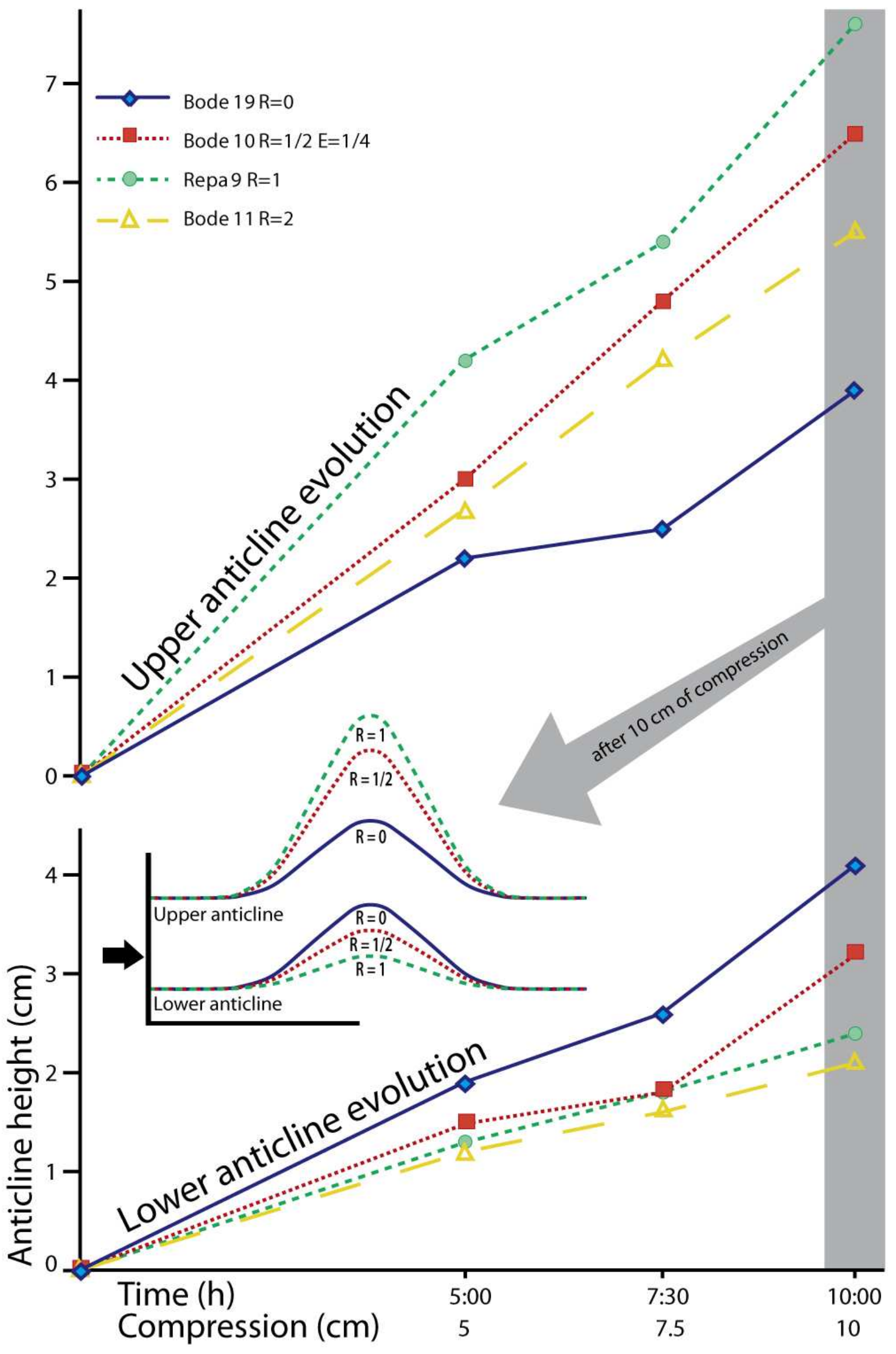




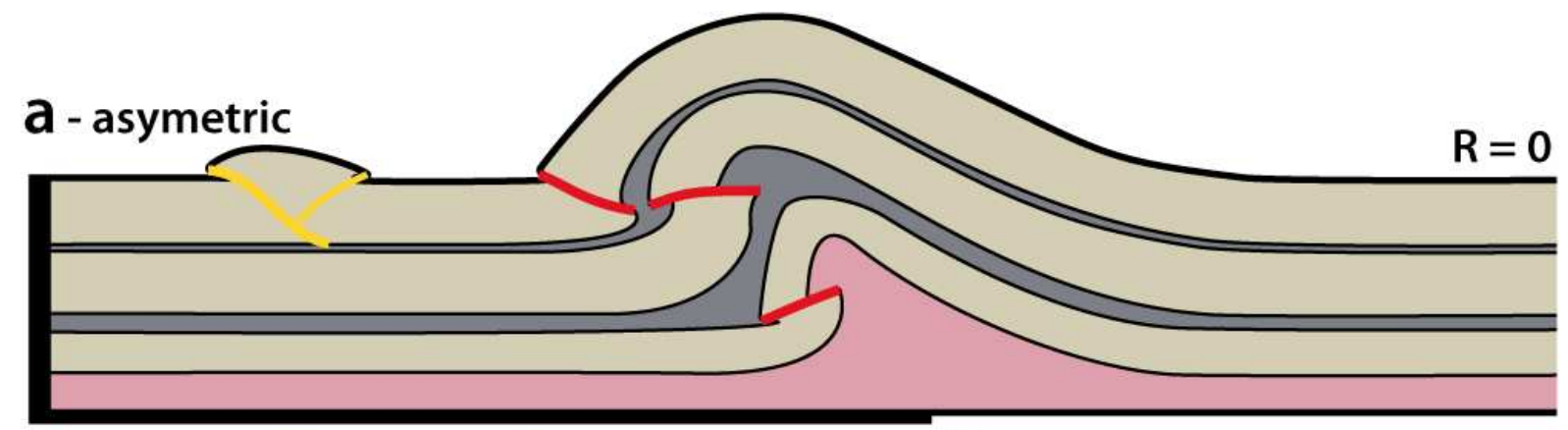

$\backslash$ early fault \late fault \permanent active fault VD

b - drastic vergence change

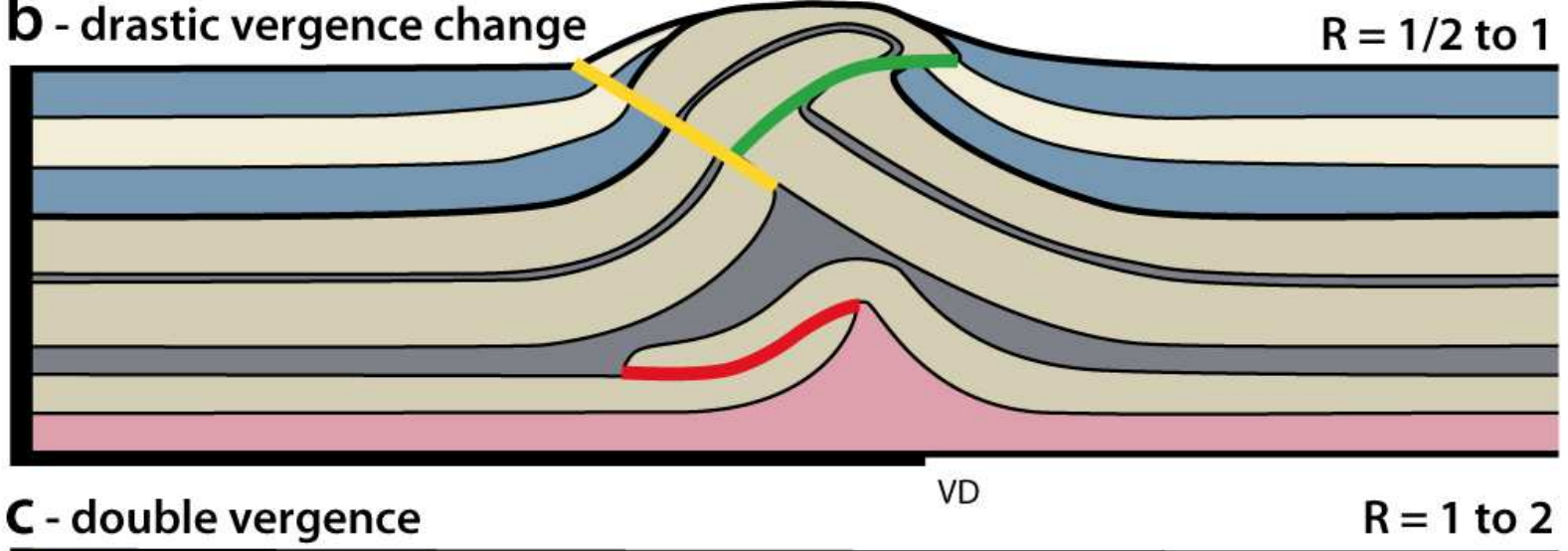

C - double vergence

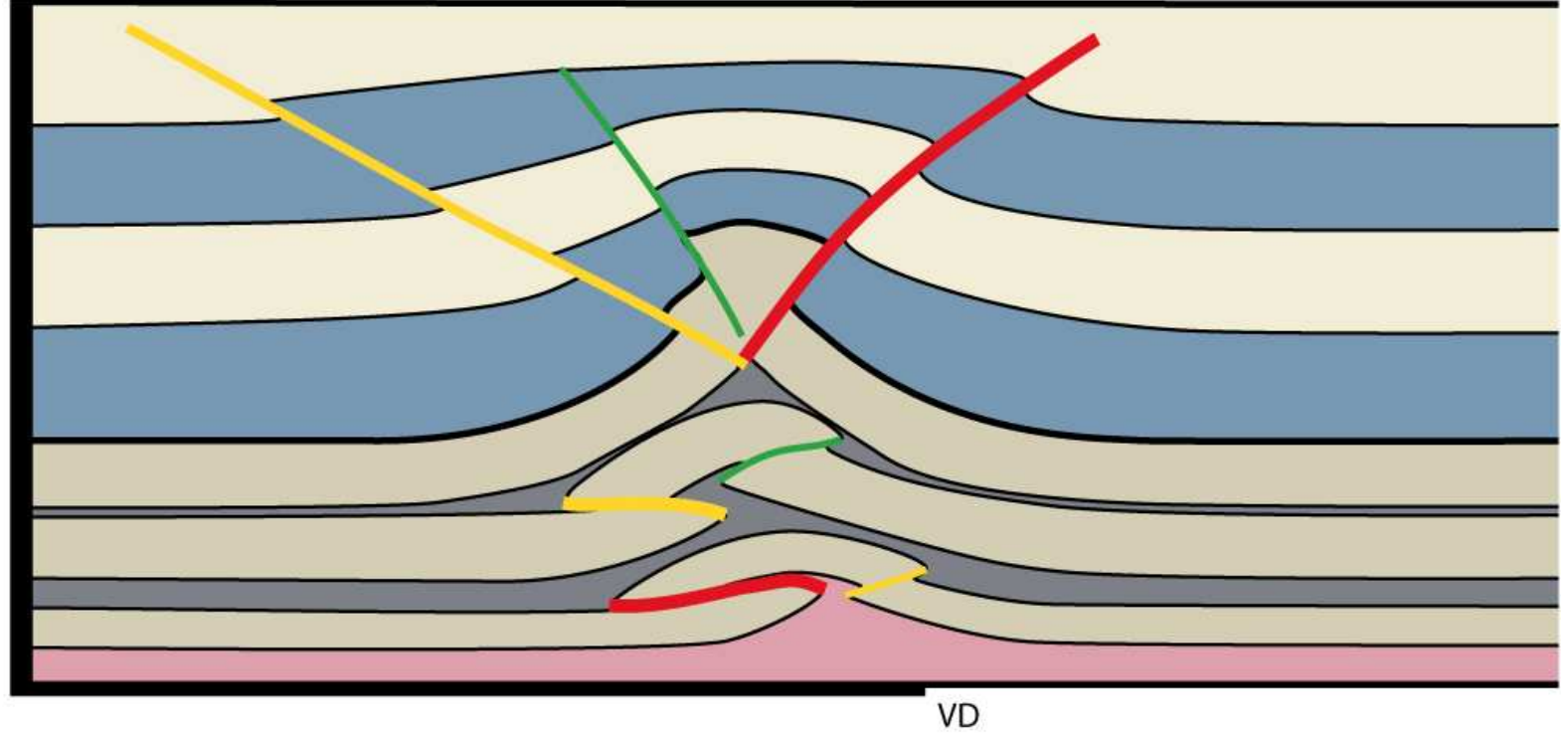



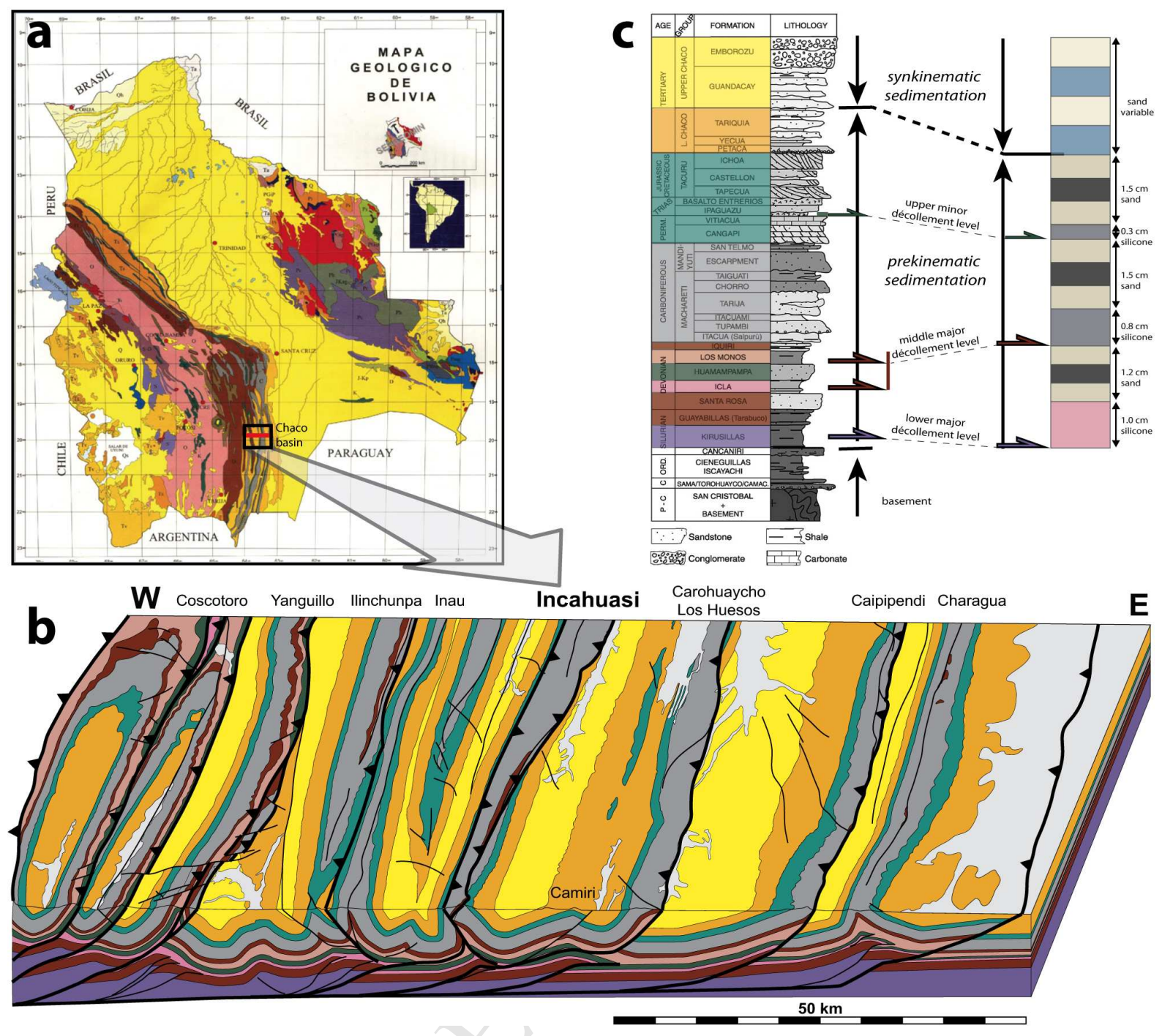


\section{a - Subsurface data}

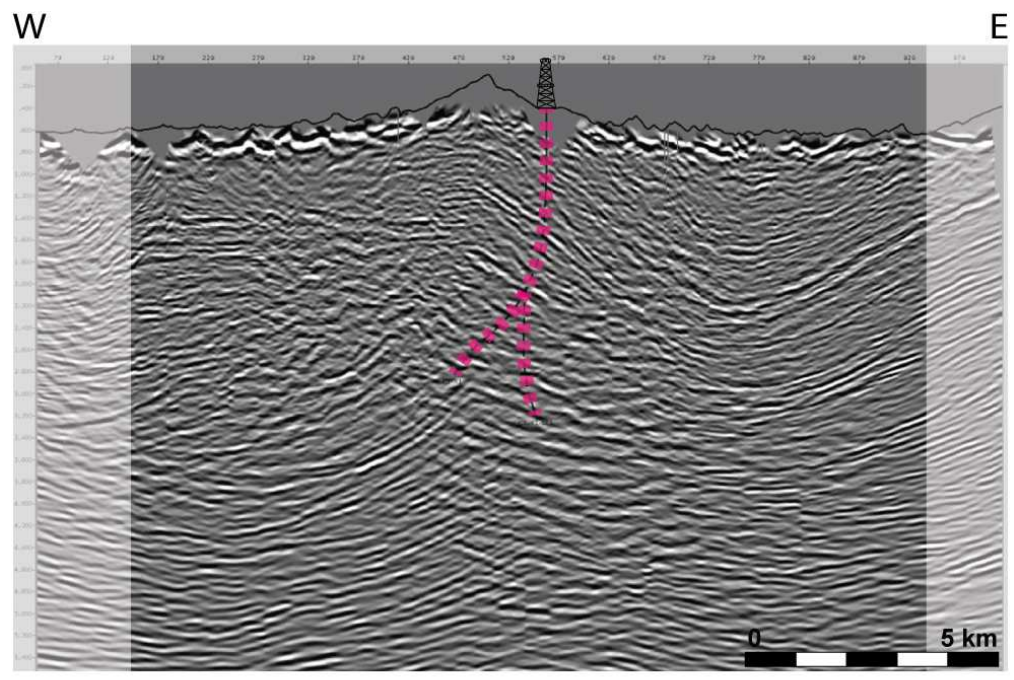

\section{b - Interpretation of Incahuasi structure}

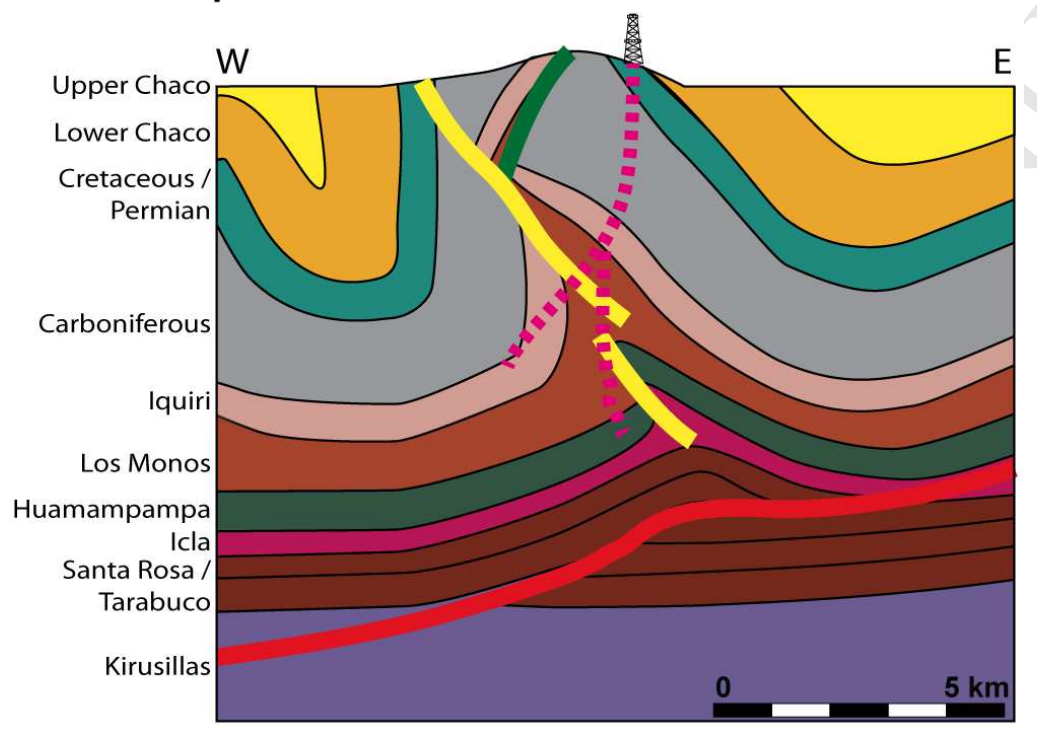

\section{c - Cross-section of experiment}

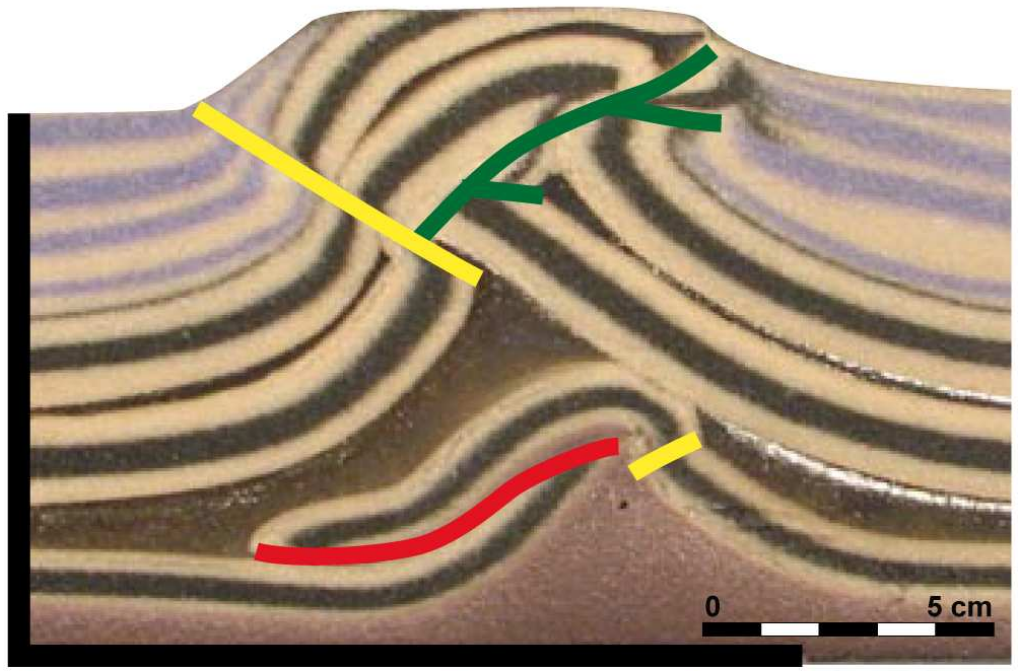

\permanent active fault \early fault late fault 


\section{HIGHLIGHTS}

- With décollement levels, models of compressive system show fish-tail structure

- Synkinematic sedimentation favour vertical uplift and double vergence in thrust structure

- Models allow to better interpret seismic lines in compressive systems

- The evolution of Subandean structures is related to shortening and mass transfer 